\title{
HUBUNGAN ANTARA DERAJAT MEROKOK AKTIF, RINGAN, SEDANG DAN BERAT DENGAN KADAR SATURASI OKSIGEN DALAM DARAH $\left(\mathrm{SpO}_{2}\right)$
}

\author{
Wahyu Tri Sudaryanto \\ Pascasarjana Ilmu Kesehatan Masyarakat Universitas Sebelas Maret
}

\begin{abstract}
Degree Of Smoking, Oxygen Saturation, Cigarettes. Smoking is tobacco smoke inhalation activity detrimental to the health of the body that are addictive. Category degrees smoking in Brinkman index is divided into three types of categories: mild, moderate and severe. The more severe the degree of smoke someone then the higher the harmful substances that are inhaled by the body and will affect the value of the oxygen saturation in the blood. This study aimed to penitian was to determine the relationship of the degree of smoking with oxygen saturation levels in the blood. The study was an observational study with cross-sectional design. The sample in this study amounted to 90 people were taken through purposive sampling method, measurement in research using measuring devices such as Brinkman index to measure the degree of smoking while using oxygen saturation value measurement tools oximetry measuring pulse. From the results of the test to get the correlative Somers'd $p<0.05$ on the relationship between the degree of smoking with oxygen saturation values. There is a relationship between the degree of smoking with oxygen saturation levels in the blood.
\end{abstract}

Keywords: Degree Of Smoking, Oxygen Saturation, Cigarettes.

Abstrak : Derajat Merokok, Saturasi Oksigen, Rokok. Merokok adalah aktivitas menghirup asap tembakau yang merusak kesehatan tubuh yang bersifat adiktif. Kategori derajat merokok dalam indeks Brinkman terbagi menjadi tiga jenis kategori yaitu ringan, sedang dan berat. Semakin berat derajat merokok seseorang maka akan semakin tinggi pula zat-zat berbahaya yang dihirup oleh tubuh dan akan mempengaruhi nilai saturasi oksigen dalam darah. Penelitian ini bertujuan dalam penitian ini adalah untuk mengetahui hubungan derajat merokok dengan kadar saturasi oksigen dalam darah. Jenis penelitian adalah penelitian observasional dengan desain cross-sectional. Sampel dalam penelitian ini berjumlah 90 orang diambil melalui metode Purposive sampling, pengukuran dalam penelitian menggunakan alat ukur berupa Indeks Brinkman untuk mengukur derajat merokok sedangkan pengukuran nilai saturasi oksigen menggunakan alat bantu ukur pulse oximetri. Dari hasil uji korelatif Somers'd test mendapatkan hasil $\mathrm{p}<0,05$ pada hubungan antara derajat merokok dengan nilai saturasi oksigen. Ada hubungan antara derajat merokok dengan kadar saturasi oksigen dalam darah.

Kata Kunci : Derajat Merokok, Saturasi Oksigen, Rokok. 
PENDAHULUAN

Global Adults Tobacco Survey (GATS) memperkirakan terdapat 7,9 milyar orang dewasa saat ini perokok aktif dan 3,5 milyar orang terpapar asap rokok di tempat kerja. Hampir 2/3 perokok di dunia tinggal di 10 negara dan Indonesia menempati urutan ke-4 dengan jumlah perokok (4\%) setelah China (38\%), Rusia (7\%) dan Amerika Serikat (5\%). Menurut survei konsumsi rokok di Indonesia cenderung meningkat menjadi $(36,3 \%)$ di tahun 2013 yang awalnya hanya (34,7\%) pada tahun 2010. Karena kebanyakan masyarakat Indonesia baik remaja maupun orang dewasa berpikir bahwa tidak ada efek dari merokok pada tubuh mereka sampai mereka mencapai usia pertengahan (Riskesdas, 2013). Padahal efek jangka panjang dari merokok sangat berbahaya bagi manusia, salah satunya gangguan kardiovaskuler meliputi jantung dan semua pembuluh darah yang membawa darah ke keseluruh tubuh yang disebabkan paparan karbon monoksida (CO) pada saat merokok (Hoffman, 2011). Karbon monoksida merupakan gas yang tidak berbau yang dihasilkan oleh pembakaran yang tidak sempurna dari unsur zat arang atau karbon. Gas karbon monoksida bersifat toksis yang bertentangan dengan oksigen, ketika kadar CO dalam darah meningkat, kemampuan tubuh untuk membawa oksigen secara signifikan menurun. Hal ini karena karbon monoksida menempel hemoglobin (pigmen pembawa oksigen dalam sel darah merah) jauh lebih mudah daripada membawa oksigen sehingga dapat menurunkan kadar oksigen dalam darah (Er et al., 2011).

Balcerzak et al. (2013) menyatakan bahwa para perokok lebih dari satu bungkus rokok per hari memiliki sel darah merah lebih besar bila dibandingkan dengan yang bukan perokok. Peningkatan massa sel darah merah dijelaskan sebagai respon terhadap jaringan yang kekurangan suplai oksigen akibat dari paparan karbon monoksida (CO) dan dapat mengurangi afinitas oksigen terhadap hemoglobin, sehingga dapat mempengaruhi kadar saturasi oksigen dalam darah. Saturasi oksigen adalah ukuran seberapa banyak prosentase oksigen yang mampu dibawa oleh hemoglobin (Hoeger, 2011). Saturasi O2 normal adalah $96 \%$ hingga $98 \%$ sesuai dengan ( $\mathrm{Pa} \mathrm{O} 2$ ) yang berkadar sekitar 80 $\mathrm{mmHg}$ hingga $100 \mathrm{mmHg}$ (Price dan Wilson, 2006). Menurut Balcerzak et al. (2013) kadar oksigen dalam darah bisa dipengaruhi karena paparan karbon monoksida kronis yang dihirup lewat hidung masuk paru-paru kemudian diikat oleh hemoglobin dan diedarkan keseluruh tubuh. Biasanya massa sel darah merah rata-rata pada perokok secara signifikan lebih besar daripada yang bukan perokok.

Berdasarkan latar belakang tersebut, penulis tertarik untuk melakukan penelitian mengenai hubungan antara derajat merokok aktif ringan, sedang dan berat dengan kadar saturasi oksigen dalam darah $\left(\mathrm{SpO}_{2}\right)$. Tujuan dari penelitian ini adalah untuk mengetahui hubungan antara derajat merokok aktif, ringan, sedang dan berat dengan kadar saturasi oksigen dalam darah $\left(\mathrm{SpO}_{2}\right)$.

WHO (2000) mendefinisikan bahwa merokok aktif adalah aktifitas menghisap rokok secara rutin minimal satu batang sehari. Ditambahkan menurut Sudoyo (2009) definisi perokok adalah orang yang telah merokok 1 batang atau lebih tiap hari sekurang-kurangnya selama 1 tahun, jika selama 1 bulan meninggalkan rokok (tidak merokok) 
disebut sebagai riwayat perokok. Jika selama 5 tahun berhenti merokok maka disebut sebagai mantan perokok (Leffondre et al,. 2002).

Bahan dasar rokok adalah tembakau. Tembakau merupakan tanaman yang dapat menimbulkan adiksi karena mengandung nikotin dan juga zat-zat karsinogen serta zat-zat beracun lainnya. Setelah diolah menjadi suatu produk apakah rokok atau produk lain, zat-zat kimia yang ditambahkan berpotensi untuk menimbulkan kerusakan jaringan tubuh serta kanker.

Saturasi oksigen adalah ukuran seberapa banyak prosentase oksigen yang mampu dibawa oleh hemoglobin (Kozier dan Erb, 2002). Saturasi O2 normal adalah $96 \%$ hingga $98 \%$ sesuai dengan $\mathrm{PaO} 2$ yang berkadar sekitar $80 \mathrm{mmHg}$ hingga $100 \mathrm{mmHg}$. Saturasi oksigen adalah presentasi hemoglobin yang berikatan dengan oksigen dalam arteri, saturasi oksigen normal adalah antara $95-100 \%$. Dalam kedokteran, oksigen saturasi (SO2), sering disebut sebagai "SATS", untuk mengukur persentase oksigen yang diikat oleh hemoglobin di dalam aliran darah. Pada tekanan parsial oksigen yang rendah, sebagian besar hemoglobin terdeoksigenasi, maksudnya adalah proses pendistribusian darah beroksigen dari arteri ke jaringan tubuh. Pada sekitar 90\% (nilai bervariasi sesuai dengan konteks klinis) saturasi oksigen meningkat menurut kurva disosiasi hemoglobinoksigen dan pendekatan $100 \%$ pada tekanan parsial oksigen> $10 \mathrm{kPa}$. Saturasi oksigen atau oksigen terlarut (DO) adalah ukuran relatif dari jumlah oksigen yang terlarut atau dibawa dalam media tertentu. Hal ini dapat diukur dengan probe oksigen terlarut seperti sensor oksigen atau optode dalam media cair (Price \& Wilson, 2006).
Pengukuran gas darah arteri adalah cara terbaik untuk menilai perubahan gas, oleh karena itu pulse oximetry sebagai cara non invasif untuk menilai oksigenasi, mulai banyak digunakan. Pulse oximetry mengukur saturasi oksigen $\mathrm{Hb}$ (saturasi O2). Saturasi O2 normal adalah $96 \%$ hingga $98 \%$ sesuai dengan $\mathrm{Pa} \mathrm{O} 2$ yang berkadar sekitar $80 \mathrm{mmHg}$ hingga 100 $\mathrm{mmHg}$ (Price dan Wilson, 2006). Nilai saturasi $\mathrm{O} 2$ hasil pemeriksaan dengan pulse oximetry adalah indikator prosentase haemoglobin tersaturasi dengan oksigen pada saat pemeriksaan. Pulse oximetry terdiri atas 2 sensor yaitu; sinar infrared yang dapat diabsorbsi oleh oxyhaemoglobin, sedangkan sinar red yang dapat diabsorbsi oleh $\mathrm{Hb}$. Nilai saturasi $\mathrm{O} 2$ menunjukkan status oksigenasi dengan akurasi pengukuran dipengaruhi oleh $\mathrm{Hb}$, arterial blood flow, suhu pada area sensor, kemampuan oksigenasi klien, fraksi oksigen (FiO2), ventilation/perfusion mismatch, kekuatan sensor sinar dan aliran balik vena pada area sensor. Alat pulse oximetry meliputi; monitor dan saturasi oksigen meter, kabel dan sensor saturasi oksigen dan zat pembersih yang direkomendasikan (Wiegand \& Carlson, 2005).

\section{METODE PENELITIAN}

Penelitian ini dilaksanakan di Dukuh Biru, Desa Pandanan, Kecamatan Wonosari, Kabupaten Klaten pada bulan Maret 2015. Penelitian ini bersifat observasi sistematis dimana di dalamnya berisikan faktor yang diperlukan dan sudah dikelompokkan ke dalam kategorikategori. Didahului dengan observasi partisipatif pendahuluan guna mencari penemuan dan perumusan masalah yang akan dijadikan sasaran observasi dengan menggunakan metode cross sectional. 
Dalam penelitian cross sectional peneliti melakukan observasi atau pengumpulan data pada satu saat yang artinya tiap subjek hanya dilakukan observasi satu kali saja, dan pengukuran pada varibel subjek dilakukan pada saat pemeriksaan tersebut. Semua subjek tidak harus diamati pada waktu yang sama.

Populasi dari penelitian ini adalah perokok aktif, jumlah populasi perokok aktif sebanyak 150 orang. Teknik pengambilan sampel menggunakan purposive sampling berdasarkan ciri atau sifat-sifat populasi yang sudah diketahui sebelumnya. Dari jumlah populasi sampel diambil berdasarkan kriteria inklusi dan ekslusi.

Kriteria Inklusi dari penelitian ini adalah: (1) warga Dukuh Biru, Desa Pandanan, Kecamatan Wonosari, Kabupaten Klaten, (2) perokok aktif yang merokok sedikitnya satu batang perhari selama sekurang-kurangnya satu tahun, (3) tidak melakukan aktifitas olahraga sebelum melakukan pemeriksaan, (4) bersedia memberikan data yang nyata dan kooperatif dengan peneliti dan (5) lakilaki perokok aktif. Sedangkan kriteria eksklusi dari penelotian ini adalah: (1) ada riwayat penyakit jantung dan paru, (2) keracunan karbon monoksida, (3) kelebihan berat badan dan (4) penderita anemia.

Salah satu pengukuran yang digunakan untuk melihat derajar merokok adalah dengan menggunakan Indeks Brinkman, dengan beberapa hal yang perlu diketahui dari responden adalah dengan beberapa item kuisioner antara lain : (1) sudah berapa tahun merokok?, (2) kapan mulai merokok?, (3) apakah sekarang masih merokok?, (4) berapa ratarata batang rokok yang dikonsumsi perhari? dan (5) jika sudah berhenti, kapan berhenti merokok?

Saturasi oksigen adalah ukuran seberapa banyak prosentase oksigen yang mampu dibawa oleh hemoglobin (Kozier \& Erb, 2002). Saturasi O2 normal adalah $96 \%$ hingga $98 \%$ sesuai dengan $\mathrm{PaO} 2$ yang berkadar sekitar $80 \mathrm{mmHg}$ hingga $100 \mathrm{mmHg}$ (Price \& Wilson, 2006). Saturasi oksigen diukur dengan cara menggunakan pulse oximetry sebagai cara non invasif (Balcerzak et all, 2013).

Data kualitatif, dinyatakan dengan kategori, karakteristik atau variable seperti baik, sedang, kurang baik, tidak baik, tinggi, sedang, rendah. Sedangkan data kuantitatif, dinyatakan dengan menggunakan angka-angka seperti skor dari hasil tes. Teknik pengumpulan data, data-data yang diperlukan untuk menunjang penelitian ini adalah kuisioner berupa identitas subyek, informasi merokok dan pemeriksaan dengan menggunakan pulsy oximetry.

Analisa data diawali dengan penentuan jenis hipotesis, dalam penelitian ini yang akan digunakan adalah uji hipotesis korelatif, uji korelasi yang akan digunakan adalah uji Somer's $D$ karena kedudukan dua variabel dalam bentuk ordinal, dimana tingkat derajat merokok sebagai variabel bebas dan tingkat saturasi oksigen sebagai variabel terikat. Pengambilan hasil keputusan berdasarkan dari hasil intepretasi nilai signifikansi, jika $\mathrm{p}<0,05$ maka korelasinya adalah bermakna, dan $\mathrm{p}>$ 0,05 korelasinya adalah tidak bermakna. Tehnik analisa data untuk mencari korelasi dari dua kelompok sampel akan menggunakan aplikasi software SPSS inc for Statistic realease 17.0, dengan mencari korelasi melalui uji Somer's $D$, interpretasinya akan membuktikan 
hipotesis dari penelitian ini adakah hubungan antara derajat merokok dengan saturasi oksigen pada perokok di Dukuh Biru, Desa Pandanan, Kecamatan Wonosari, Kabupaten Klaten.

\section{HASIL PENELITIAN}

Penelitian ini dilakukan di Dukuh Biru, Desa Pandanan, Kecamatan Wonosari, Kabupaten Klaten pada bulan Maret 2015. Dalam penelitian ini mendapatkan sampel penelitian sebanyak 90 orang responden. Penelitian ini bertujuan untuk mengetahui hubungan derajat merokok dengan kadar saturasi oksigen dalam darah. Pengambilan data derajat merokok dengan menggunakan instrument indeks Brinkman sedangkan untuk pengambilan data saturasi oksigen menggunakan instrumen pulse oximetry. Dengan uraian hasil sebagai berikut :

1. Karakteristik responden menurut umur

Distribusi responden berdasarkan umur disajikan pada tabel di bawah:

\section{Tabel 1}

\section{Distribusi Responden Berdasarkan}

\begin{tabular}{lll}
\multicolumn{3}{c}{ Umur } \\
\hline Umur & Frekuensi & Prosentase \\
\hline $17-24$ & 29 & $32,2 \%$ \\
$25-32$ & 16 & $17,8 \%$ \\
$33-40$ & 19 & $21,1 \%$ \\
$41-48$ & 6 & $6,7 \%$ \\
$49-56$ & 7 & $7,8 \%$ \\
$57-64$ & 5 & $5,6 \%$ \\
$65-72$ & 4 & $4,4 \%$ \\
$73-80$ & 4 & $4,4 \%$ \\
\hline Jumlah & 90 & $100 \%$ \\
\hline
\end{tabular}

Berdasarkan tabel 1 di atas diketahui bahwa responden terbanyak adalah rentan umur 17-24 tahun sebanyak 29 orang $(32,2 \%)$.

2. Karakteristik responden menurut lama merokok

Distribusi responden berdasarkan lama merokok disajikan pada tabel di bawah:
Tabel 2

Distribusi Responden Berdasarkan Lama Merokok

\begin{tabular}{lll}
\hline $\begin{array}{l}\text { Lama } \\
\text { merokok }\end{array}$ & Frekuensi & Prosentase \\
\hline $1-8$ & 35 & $38,9 \%$ \\
$9-16$ & 24 & $26,7 \%$ \\
$17-24$ & 10 & $11,1 \%$ \\
$25-32$ & 8 & $8.9 \%$ \\
$33-40$ & 4 & $4,4 \%$ \\
$41-48$ & 5 & $5,6 \%$ \\
$49-56$ & 4 & $4,4 \%$ \\
\hline Jumlah & 90 & $100 \%$ \\
\hline \multicolumn{2}{c}{ Berdasarkan tabel 2 di atas }
\end{tabular}

diketahui bahwa responden terbanyak adalah yang telah merokok 1-8 tahun dengan jumlah sebanyak 35 orang $(38,9 \%)$.

3. Karakteristik responden berdasarkan jumlah rokok perhari

Distribusi responden berdasarkan jumlah merokok perhari disajikan pada tabel di bawah:

Tabel 3

Distribusi Responden Berdasarkan Jumlah Rokok Perhari

\begin{tabular}{lll}
\hline $\begin{array}{l}\text { Jumlah rokok } \\
\text { perhari }\end{array}$ & Frekuensi & Prosentase \\
\hline $1-3$ & - & $0 \%$ \\
$4-6$ & 15 & $16,7 \%$ \\
$7-9$ & 2 & $2,2 \%$ \\
$10-12$ & 41 & $45,6 \%$ \\
$13-15$ & 1 & $1,1 \%$ \\
$16-19$ & 31 & $34,4 \%$ \\
\hline Jumlah & 90 & $100 \%$ \\
\hline \multicolumn{2}{r}{ Berdasarkan tabel } & 3 di atas
\end{tabular}

diketahui bahwa responden terbanyak adalah yang dalam satu hari merokok 10 12 batang dengan jumlah sebanyak 41 orang $(45,6 \%)$.

4. Karakteristik responden berdasarkan kategori Brinkman

Distribusi responden berdasarkan kategori merokok indeks Brinkman disajikan pada tabel di bawah: 
Tabel 4

Distribusi Responden Berdasarkan Kategori Indeks Brinkman

\begin{tabular}{lll}
\hline $\begin{array}{l}\text { Jumlah rokok } \\
\text { perhari }\end{array}$ & Frekuensi & Prosentase \\
\hline Ringan & 51 & $56,7 \%$ \\
Sedang & 33 & $36,7 \%$ \\
Berat & 6 & $6,6 \%$ \\
\hline Jumlah & 90 & $100 \%$ \\
\hline \multicolumn{2}{c}{ Berdasarkan tabel 4}
\end{tabular}

diketahui bahwa responden dalam indeks Brinkman terbanyak adalah yang dalam kategori ringan dengan jumlah sebanyak 51 orang $(56,7 \%)$.

5. Karakteristik responden berdasarakan jenis rokok

Distribusi responden berdasarkan kategori jenis rokok disajikan pada tabel di bawah:

Tabel 5

Distribusi Responden Berdasarkan Kategori Jenis Rokok

\begin{tabular}{lll}
\hline Jenis rokok & Frekuensi & Prosentase \\
\hline Mild & 24 & $26,7 \%$ \\
Filter & 34 & $37,8 \%$ \\
Kretek & 24 & $26,7 \%$ \\
Ganti-ganti & 8 & $8,8 \%$ \\
\hline Jumlah & 90 & $100 \%$ \\
\hline
\end{tabular}

Berdasarkan tabel 5 di atas diketahui bahwa jenis rokok terbanyak adalah jenis filter dengan jumlah sebanyak 34 orang $(37,8 \%)$.

6. Karakteristik responden berdasarkan kategori saturasi oksigen

Distribusi responden berdasarkan kategori saturasi oksigen disajikan pada tabel di bawah:

Tabel 6

Distribusi Responden Berdasarkan Kategori Saturasi Oksigen

\begin{tabular}{lll}
\hline Saturasi oksigen & Frekuensi & Prosentase \\
\hline Baik & 60 & $66,7 \%$ \\
Buruk & 30 & $33,3 \%$ \\
\hline Jumlah & 90 & $100 \%$ \\
\hline
\end{tabular}

Berdasarkan tabel 6 di atas diketahui bahwa kategori saturasi oksigen terbanyak adalah dalam kategori baik dengan jumlah sebanyak 60 orang $(66,7 \%)$.

Uji pertama bertujuan untuk mengetahui adakah makna korelasi antara derajat obstruksi kronis dengan nilai kualitas hidup, dan kesimpulan lain dari uji ini akan menginterpretasikan nilai korelasi yang menunjukkan kuat atau lemahnya korelasi tersebut.

1. Hasil uji hubungan jenis rokok dengan kadar saturasi oksigen. Dengan hasil sebagai berikut :

\section{Tabel 7}

Hasil Uji Somers'd Test

\begin{tabular}{lc}
\hline Jenis Uji & Signifikansi \\
\hline Somers'd & 0,000 \\
\hline \multicolumn{1}{c}{ Hasil pada penilaian uji korelatif }
\end{tabular}

Hasil pada penilaian uji korelatif Somer's $D$ menunjukkan nilai signifikansi $\mathrm{p}<0,05$ pada hasil uji hubungan antara jenis rokok dengan nilai saturasi oksigen. Yang berarti menunjukkan ada hubungan antara jenis rokok dengan nilai saturasi oksigen. Hal ini dapat dilihat pada tabel 4.8 dimana mendapatkan hasil bahwa responden dengan nilai saturasi oksigen baik terbanyak merokok rokok berjenis mild, sedangkan pada responden dengan nilai saturasi oksigen buruk terbanyak merokok berjenis kretek.

Tabel 8

Distribusi Responden Berdasarkan

Korelasi Jenis Rokok Dan Saturasi

Oksigen

\begin{tabular}{llll}
\hline Indeks & \multicolumn{2}{l}{ Kategori Saturasi } & Total \\
\cline { 2 - 3 } Brinkman & Baik & Buruk & \\
\hline Mild & 24 & 0 & 24 \\
Filter & 22 & 12 & 34 \\
Kretek & 8 & 16 & 24 \\
Ganti-ganti & 6 & 2 & 8 \\
Jumlah & 60 & 30 & 90 \\
\hline
\end{tabular}


Berdasarkan tabel 8 di atas diketahui bahwa kategori saturasi oksigen baik terbanyak dimiliki oleh responden dengan kategori jenis rokok mild dengan jumlah 24 responden, sedangkan saturasi oksigen buruk dimiliki oleh responden dengan kategori jenis rokok kretek dengan responden sebanyak 16 responden.

2. Hasil uji hubungan kategori derajat merokok indeks Brinkman dengan kadar saturasi oksigen. Dengan hasil sebagai berikut :

\section{Tabel 9}

Hasil Uji Somer's D Test

\begin{tabular}{ll}
\hline Jenis Uji & Signifikansi \\
\hline Somer's $D$ & 0,000 \\
\hline
\end{tabular}

Hasil pada penilaian uji korelatif Somer's $D$ menunjukkan nilai signifikansi $\mathrm{p}<0,05$ pada hasil uji hubungan antara kategori derajat merokok indeks Brinkman dengan nilai saturasi oksigen. Yang berarti ada hubungan antara kategori derajat merokok indeks Brinkman dengan nilai saturasi oksigen.

Kategori saturasi oksigen baik terbanyak dimiliki oleh responden dengan indeks Brinkman pada kategori ringan dengan jumlah 42 responden (70\%), kemudian diikuti oleh indeks Brinkman kategori sedang dengan jumlah 17 responden $(28,3 \%)$ dan terkahir oleh indeks Brinkman kategori berat dengan jumlah 1 responden $(1,7 \%)$. Saturasi oksigen buruk terbanyak dimiliki oleh responden dengan indeks Brinkamn pada kategori sedang sebanyak 16 responden $(53,3 \%)$ kemudian diikuti oleh responden dengan indeks Brinkman dengan kategori ringan sebanyak 9 responden $(30 \%)$ dan terkahir dimiliki oleh indeks Brinkman kategori berat dengan jumlah 5 responden $(16,7 \%)$.
3. Hasil uji hubungan umur dengan kadar saturasi oksigen. Dengan hasil sebagai berikut :

Tabel 10

Hasil Uji Somers'd Test

\begin{tabular}{cc}
\hline Jenis Uji & Signifikansi \\
\hline Somers'd & 0,000 \\
\hline Hasil pada & penilaian uji korelatif
\end{tabular}

Somer's $D$ menunjukkan nilai signifikansi $\mathrm{p}<0,05$ pada hasil uji hubungan antara umur dengan nilai saturasi oksigen. Yang berarti menunjukkan ada hubungan antara umur dengan nilai saturasi oksigen. Hal ini didukung oleh penelitian dari Yunus dkk (2011) yang mendapatkan hasil bahwa fungsi pernapasan dan sirkulasi darah akan meningkat dari masa kanakkanak dan jadi optimal pada umur 20-30 tahun. Sesudah itu akan terjadi penurunan. Setelah mencapai titik maksimal pada umur dewasa muda, difusi, ventilasi, ambilan oksigen dan semua parameter faal paru akan turun sesuai dengan pertambahan umur.

4. Hasil uji hubungan tinggi badan dengan kadar saturasi oksigen. Dengan hasil sebagai berikut :

\section{Tabel 11}

Hasil Uji Somers'd Test

\begin{tabular}{ll}
\hline Jenis Uji & Signifikansi \\
\hline Somers'd & 0,000
\end{tabular}

Hasil pada penilaian uji korelatif Somer's $D$ menunjukkan nilai signifikansi $\mathrm{p}<0,05$ pada hasil uji hubungan antara tinggi badan dengan nilai saturasi oksigen. Yang berarti menunjukkan ada hubungan antara tinggi badan dengan nilai saturasi oksigen. Tinggi badan menurut Crosbiee mempengaruhi luas dari paru-paru, sehingga nilai sehingga terdapat hubungan antara tinggi badan dan kadar saturasi oksigen. 
5. Hasil uji hubungan berat badan dengan kadar saturasi oksigen. Dengan hasil sebagai berikut :

\section{Tabel 12}

Hasil Uji Somers'd Test

\begin{tabular}{ll}
\hline Jenis Uji & Signifikansi \\
\hline Somers'd & 0,071 \\
\hline
\end{tabular}

Hasil pada penilaian uji korelatif Somer's $D$ menunjukkan nilai signifikansi $\mathrm{p}>0,05$ pada hasil uji hubungan antara tinggi badan dengan nilai saturasi oksigen. Yang berarti menunjukkan ada hubungan antara tinggi badan dengan nilai saturasi oksigen. Berat badan tidak berpengaruh secara signifikan terhadap saturasi oksigen, hal ini dikarenakan berat badan tidak mempengaruhi secara langsung terhadap faal paru, yang berarti tidak memiliki pengaruh terhadap kinerja dari paru-paru.

\section{PEMBAHASAN}

Peneliti mendapatkan jumlah responden sebanyak 90 orang dengan distribusi menurut umur mendapatkan hasil terbanyak responden dengan rentang umur 17-25 tahun sebanyak 34 orang $(37,8 \%)$. Hal ini menunjukkan bahwa perokok usia terbanyak adalah rentang umur remaja dewasa.

Jumlah responden sebanyak 90 orang dengan distribusi menurut lama merokok mendapatkan hasil terbanyak responden dengan rentang yang telah merokok 1-8 tahun dengan jumlah sebanyak 35 orang $(38,9 \%)$. Jumlah responden sebanyak 90 orang dengan distribusi menurut jumlah rokok perhari mendapatkan hasil terbanyak responden dengan satu hari merokok $10-12$ batang dengan jumlah sebanyak 41 orang $(45,6 \%)$.

Penelitian ini mendapatkan hasil responden dengan kategori terbanyak dalam skala indeks Brinkman adalah dalam kategori perokok ringan dengan jumlah responden sebanyak 51 responden $(56,7 \%)$ kemudian sisanya adalah kategori sedang dengan jumlah sampel sebanyak 33 responden $(36,7 \%)$ dan yang paling sedikit adalah dengan kategori berat dengan jumlah sampel sebanyak 6 responden (6,6\%). Responden dengan kategori terbanyak dalam jenis rokok yang dihisap adalah jenis filter dengan jumlah sebanyak 34 orang $(37,8 \%)$. Responden dengan kategori terbanyak dalam kategori saturasi oksigen terbanyak adalah dalam kategori baik dengan jumlah sebanyak 60 orang $(66,7 \%)$.

Hasil pada penilaian hubungan antara kategori derajat merokok indeks Brinkman dengan nilai saturasi oksigen yang diukur dengan menggunakan pulsa Oksimetri yang mengukur kadar oksigen di darah arteri menunjukkan nilai signifikansi $\mathrm{p}<0,05$ dimana ada hubungan antara derajat merokok aktif, ringan, sedang dan berat dengan nilai saturasi oksigen dalam darah. Hal ini sesuai dengan tabel 4.7 yang mendapatkan hasil bahwa semakin tinggi derajat merokok seseorang maka nilai saturasi oksigen akan buruk. Hal ini diketahui dari hasil penelitian bahwa kategori saturasi oksigen baik terbanyak dimiliki oleh responden dengan indeks Brinkman pada kategori ringan dengan jumlah 42 responden. Saturasi oksigen buruk terbanyak dimiliki oleh responden dengan indeks Brinkamn pada kategori sedang sebanyak 16 responden $(53,3 \%)$ kemudian diikuti oleh responden dengan indeks Brinkman dengan kategori ringan sebanyak 9 responden $(30 \%)$ dan terkahir dimiliki oleh indeks Brinkman kategori berat dengan jumlah 5 responden $(16,7 \%)$. Hal ini sesuai dengan penelitian dari Finch et 
al., (1990) yang mana perokok memiliki nilai saturasi yang buruk dalam nilai saturasi oksigen dalam darah.

Derajat merokok seseorang adalah nilai hitung jumlah rokok yang dikonsumsi selama satu tahun, jadi berarti semakin tinggi derajat merokok seseorang maka jumlah batang rokok yang dihisap dalam satu harinya lebih dari 10 batang perhari atau telah lama merokok dalam hitungan tahun. Nilai derajat merokok mempengaruhi nilai saturasi oksigen seseorang karena setiap satu batang rokok yang dibakar akan mengeluarkan sekitar 4.000 bahan kimia diantaranya nikotin, gas karbonmonoksida, nitrogen oksida, hydrogen sianida, ammonia, akrolein, benzene dan etanol. Efek beracun karbon monoksida yang menyebabkan pelepasan ikatan oksigen dari hemoglobin menjadi bentuk carboxyhaemoglobin. Karbon monoksida (CO) adalah gas yang tidak berwarna dan tidak berbau yang dihasilkan dari proses pembakaran yang tidak sempurna dari material yang berbahan dasar karbon seperti kayu, batu bara, bahan bakar minyak dan rokok (Perdanakusuma, 2012). Keracunan karbonmonoksida dapat menyebabkan turunnya kapasitas transportasi oksigen dalam darah oleh hemoglobin dan penggunaan oksigen di tingkat seluler. Karbonmonoksida mempengaruhi berbagai organ di dalam tubuh, organ yang paling terganggu adalah yang mengkonsumsi oksigen dalam jumlah besar, seperti otak dan jantung (Eugene et al., 2003).

Efek toksisitas utama adalah hasil dari hipoksia seluler yang disebabkan oleh gangguan transportasi oksigen. $\mathrm{CO}$ mengikat hemoglobin secara reversible, yang menyebabkan anemia relatif karena CO mengikat hemoglobin 230-270 kali lebih kuat daripada oksigen. Kadar $\mathrm{HbCO}$ $16 \%$ sudah dapat menimbulkan gejala klinis. CO yang terikat hemoglobin menyebabkan ketersediaan oksigen untuk jaringan menurun (Eugene et al., 2003). Dari penelitian ini menunjukkan bahwa derajat merokok mempengaruhi kadar saturasi oksigen dalam darah, hal ini berarti bahwa semakin tinggi intensitas merokok dalam satu hari yang dikalikan dengan berapa tahun merokok akan mempengaruhi nilai kadar saturasi oksigen. Nilai derajat merokok akan mempengaruhi seberapa banyak karbonmonoksida yang dihisap oleh tubuh yang dihasilkan dari hasil pembakaran rokok (Perdanakusuma, 2012).

Hal ini didukung oleh hasil dari tabel 4.8 yang menunjukkan bahwa kategori saturasi oksigen baik terbanyak dimiliki oleh responden dengan kategori jenis rokok mild dengan jumlah 24 responden, sedangkan saturasi oksigen buruk dimiliki oleh responden dengan kategori jenis rokok kretek dengan responden sebanyak 16 responden, hal ini berarti bahwa rokok kretek berhubungan dengan nilai saturasi oksigen dalam darah. Rokok kretek dalam penelitian Wulan et al. (2003) tentang studi kadar nikotin dan tar sembilan merk rokok kretek dan filter memiliki nilai kadar nikotin dan Tar yang lebih tinggi dari rokok jenis mild rerata. Kadar Tar Rokok kretek filter berkisar antara 0,05 sampai $0,175 \% \mathrm{~b} / \mathrm{b}$. Rerata hasil pengukuran kadar nikotin rokok kretek survei berkisar antara 1,10 sampai $2,17 \% \mathrm{~b} / \mathrm{b}$. bila dibandingkan dengan SNI 0766-1989-A yang menetapkan standar kadar nikotin untuk rokok kretek filter adalah maksimum 2,0\%. Nilai kandungan Tar akan mempengaruhi kandungan nilai oksigen yang dibawa oleh Hemoglobin dan memicu munculnya sel kanker pada 
paru-paru. Sedangkan nikotin adalah senyawa yang bersifat adiktif yang akan memicu perokok untuk terus melanjutkan aktivitas merokoknya, sehingga semakin tinggi nilai nikotin dan Tar maka akan semakin mempengaruhi kadar dari saturasi oksigen dalam darah. Hal ini karena pada orang yang kecanduan rokok akibat nikotin akan mengkompensasi kebutuhan nikotin mereka dengan meningkatkan jumlah batang rokok yang diisap perhari (USDephealth, 2015).

\section{KESIMPULAN DAN SARAN}

Berdasarkan dari hasil analisa dan perhitungan uji statistik, dapat di ambil kesimpula sebagai berikut Ada hubungan antara derajat merokok aktif, ringan, sedang dan berat dengan kadar saturasi oksigen dalam darah $\left(\mathrm{SpO}_{2}\right)$. Saran yang diberikan untuk mendapatkan hasil penelitian yang lebih baik terhadap hubungan antara derajat merokok dengan kadar saturasi oksigen dalam darah adalah dengan meneliti lebih lanjut hubungan antara Nikotin, Tar dan zat dalam rokok lainnya, sehingga yang dihasilkan dari penelitian tentang kajian ini lebih dalam. Dan perlunya pengkajian tentang adakah hubungan jenis-jenis rokok dan juga faktor eksternal lain dari kadar saturasi oksigen dalam tubuh. Masih perlunya dilakukan pengkajian penelitian dengan metode yang sama terhadap karakteristik data yang lebih luas dalam penelitian lebih lanjut. Baik dengan menambah jumlah responden dan menambah variabelvariabelyang dimiliki. Sedangkan saran yang diberikan untuk responden adalah untuk berhenti merokok dan menjalani pola hidup sehat.

\section{DAFTAR RUJUKAN}

Balcerzak P Satnley, Lawrence Thomas, L. Arthur and Jr. Sagone. 2013. Effect of Smoking on Tissue Oxygen Supply. 20036. Blood (print ISSN 0006-4971, online ISSN 1528-0020), is published weekly bythe American Society of Hematology, 2021 L St, NW, Suite 900, Washington DC.

Eugene N.Bruce, Margaret C- A. 2003.

Multicompanement Model Of

Cartoxyhemoglobin And

Carboxymyoglobin Responses To Inhalation Of Carbon Monoxide. $J$ Appl Physiol95 (2003): 12351247.

Finch, C. Alan R. Tait eho, Jeffrey V. Kyff oo, Bruce Crider too, Vira Santibhavank too, David Learned. 1990. Changes in arterial oxygen saturation in cigarette smokers following general anaesthesia. From the Department of Anesthesiology, The University of Michigan Medical Center, Ann Arbor, MI 48109. CAN J ANAESTH 1990 / 37:4 / pp423-8.

Hoffman, D. and I. Hoffman. 2011. The changing cigarette: Chemical studies and bioassays, in Risks Associated with Smoking Cigarettes with Low MachineMeasured Yields of Tar and Nicotine (Smoking and Tobacco Control Monograph No. 13). 2001, NCI: Bethseda. p. 159-191.

Leffondre, K., Abrahamowicz, M., Siemiatycki, J., Rachet, B. 2002. Modelling Smoking History: A Comparison of Different Approach. American Journal of Epidemiology. 
Perdanakusuma, David. 2012. Intoksikasi Karbon Monoksida. Departemen / SMF Ilmu Bedah Plastik Fakultas Kedokteran Universitas Airlangga, RSUD Dr. Soetomo Surabaya

Price, S.A. and Wilson, L.M. 2006. Pathophysiology: clinical concepts of disease process. 6 edition, Elsevier Science.

Riskesdas. 2013. Kementrian Kesehatan Republik Indonesia. Jakarta

Sari Widya, Eriani Kartini, Fitriani. 2010. The Effect Of Cigarettes Smoke Xposured Causes Fertility Of.

Sitepoe M. 2000. Kekhususan Rokok Indonesia. Jakarta: Penerbit PT Gramedia Widiasarana.

Sudoyo. 2009. Buku Ajar Ilmu Penyakit Dalam. Jakarta: Interna Publishing

Hoeger, Werner W. K and Sharon A. Hoeger. 2011. Fitness and Welness. Belmont, USA: Wadsworth.

US Dep Health Hum Serv. 2015. Risk Associated with Smoking Cigarettes with Low MachineMeasured Yields of Tar and Nicotine. Smoking and JOM FK Vol.2 No.2 Okt 2015 7. Tobacco Control Monograph. 2001;13.

Wiegand, D.J.L.M. \& Carlson, K.K. 2005. Procedure manual for critical care. Fifth Edition. Elsevier Saunders. 11830 Westline Industrial Drive, St. Louis Missouri 63146.

WHO. 2013. Report On The Global Tobacco Epidemic.

WHO, 2000. Second Meeting of the working group A/FCTC/WG2/3 on the WHO frame work convention on Tobacco control: Provisional texts of proposed draft elements for a WHO framework convention on tobacco control.

Wulan, Siti N, Dani Alam, Sudarminto S.Y. 2003. Studi Kadar Nikotin dan Tar Sembilan Merk Rokok Kretek dan Filter yang Beredar di Wilayah Kabupaten Nganjuk. J.Tek. Pert. Vol 5. No 3. 151-155. 